\title{
Implementation of Activity-Based Costing Method In Accommodation Companies: A Case Study In A 5-Star Hotel ${ }^{1}$
}

\author{
Ömer Burak PAKSOY \\ Lecturer Dr., Alanya Alaaddin Keykubat University, \\ Gazipaşa MRB Vocational School, \\ Department of Management and Organization, \\ omer.paksoy@alanya.edu.tr, \\ ORCID ID: https://orcid.org/0000-0002-1273-5915

\section{Baki YILMAZ} \\ Prof. Dr., Selçuk University, \\ Faculty of Economics and Administrative Sciences, \\ Department of Accounting and Finance, \\ byilmaz@selcuk.edu.tr, \\ ORCID ID: https://orcid.org/0000-0002-5392-2485.
}

\begin{abstract}
The purpose of this study is to provide some empirical evidence about implementing the activity-based costing (ABC) method and how to calculate costs in a 5-star hotel operating in Alanya / Antalya and to discuss the cost results by comparing them with the traditional costing method. Due to the Covid-19 outbreak in 2020, the data of July 2019 were used to make cost calculations more accurate and healthy. While making cost calculations, the activities in the hotel are classified as four main (front office, housekeeping, service, kitchen) and one joint (including common and administrative expenses) activities. The study was adopted to the case study, and the data were obtained from the hotel officials. As a result of the study, it was concluded that $\mathrm{ABC}$ method is applicable in the case hotel and the calculated unit cost is more accurate and realistic than the traditional costing method.
\end{abstract}

Keywords: Activity-Based Costing, Traditional Costing Method, Accommodation Companies, Hotels.

\footnotetext{
${ }^{1}$ Article Arrival/Acceptance Date: 25.04.2021/05.08.2021

Reference Information: Paksoy, Ö.B. ve Yılmaz, B. (2021). Implementation of activitybased costing method in accommodation companies: a case study in a 5-star hotel. Kahramanmaraş Sütçü Imam University Journal of Social Sciences, 18 (3), 2090-2113. DOI: 10.33437/ksusbd.926678.
} 


\title{
Konaklama İşletmelerinde Faaliyet Tabanlı Maliyetleme Yönteminin Uygulanması: 5 Yıldızlı Bir Otelde Vaka Çalışması
}

\author{
Öz
}

Bu çalışmanın amacı, Alanya / Antalya'da faaliyet gösteren 5 yıldızlı bir otel işletmesinde faaliyet tabanlı maliyetleme (FTM) yönteminin uygulanması ve maliyetlerin nasıl hesaplanacağı hakkında bazı ampirik kanıtlar sağlamak ve maliyet sonuçlarını geleneksel maliyet yöntemi ile karşılaştırarak tartışmaktır. 2020'deki Covid-19 salgını nedeniyle maliyet hesaplamalarını daha doğru ve sağlıklı hale getirmek için Temmuz 2019 verileri kullanılmıştır. Maliyet hesaplamaları yapılırken oteldeki faaliyetler dört ana (ön büro, kat hizmetleri, servis, mutfak) ve bir ortak (genel ve idari giderler dahil) faaliyetler olarak sınıflandırılmıştır. Çalışmada örnek olay yöntemi benimsenmiş ve veriler otel yetkililerinden alınmıştır. Çalışma sonucunda FTM yönteminin otelcilikte uygulanabilir olduğu ve hesaplanan birim maliyetin geleneksel maliyet yöntemine göre daha doğru ve gerçekçi olduğu sonucuna varılmıştır.

Anahtar Kelimeler: Faaliyet Tabanlı Maliyetleme, Geleneksel Maliyet Yöntemleri, Konaklama İşletmeleri, Oteller.

\section{INTRODUCTION}

Today, tourism has become one of the largest industries in the world. According to the report prepared by the United Nations World Tourism Organization, as an export category worldwide, tourism ranks third after chemicals, fuels, and automotive products. In many developing countries, tourism is at the top in the export category. Tourism also can contribute, directly or indirectly, to all of the goals that have been included as targets on inclusive and sustainable economic growth, sustainable consumption, and production (UNWTO, 2020).

In Turkey, there is a significant contribution to the economy of tourism revenues. In 2020, due to the covid-19 outbreak, there was a big decrease in tourism revenues worldwide. According to the evaluation made by the United Nations World Tourism Organization, it is estimated that global tourism industry will contract by 58 to 78 percent due to the outbreak. Despite this, in 2019, Turkey has achieved approximately 34 billion US Dollars in tourism income. The share of tourism revenues in the gross domestic product was 4.6 percent. This rate is higher than the rates in other periods. Also, the number of foreign tourists visiting Turkey in 2019 was approximately 45 million (TURSAB, 2020).

Accommodation companies operating in the tourism industry have become one of the most essential business lines today. Especially in the 21st century, the 
growth in the income level of people, the increase of their leisure time, the more emphasis on the comfort and relaxation of people, the increase in travel with technology, and globalization have caused the accommodation companies to develop and become more critical in the economy. The tourism industry will be open to all changes in the globalization process. It will be a developing industry that strives to achieve success by accepting the positive features of globalization (Holjevac, 2003: 130-131).

Due to intense and global competition, companies have opted for product differentiation. As a result of this situation, new production methods have been developed in which the product variety is high but in small quantities (Kaygusuzoğlu, 2010: 245). Global and intense competition also encourages companies to use more advanced technologies leading to the development of new production systems. Constantly changing market conditions and developing technology requires new understanding and developments in cost management concepts. Traditional costing methods are insufficient to meet the needs of companies due to these developments and changes. Therefore, modern costing methods are needed to meet the needs of businesses.

Accommodation companies are service businesses that provide integrated services and perform many activities such as food and beverage, entertainment, and meetings. Controlling costs effectively in accommodation companies, increasing profitability and maintaining its existence in an intense competitive environment is only possible with an effective costing method (Kurtlu and Selçuk 2020: 262).

Contemporary costing methods are useful in companies, which is also described as modern production environments, where technology is used extensively and where product variety, resources, and activities are high. Although accommodation companies are labor-intensive due to their sectoral characteristics, they will find the opportunity to provide cost-effectiveness and control if they apply contemporary costing methods due to the large variety of resources, activities, and products.

Using new costing methods help companies to compete in these rough competiton conditions, because it helps to calculate costs accurately thus helps to control and reduce costs. Activity-based costing (ABC) method is one of these methods. ABC is considered as one of the most important innovations in cost calculation and management accounting (Gosselin, 2007: 666).

The aim of this study is to evaluate the results of the application of $A B C$ method in the basic service departments of a hotel and to discuss its impact. The results of the study are consistent with the results of other case studies made in 
this field. The study consists of two parts. In the first part, the definition and purpose of the $\mathrm{ABC}$ method, the necessity of $\mathrm{ABC}$ system in hotel companies, and other studies that are made in this field are given. In the second part, there is a case study in a 5-star hotel. Activities and cost calculations in the study differ in terms of being more detailed than other case studies. The ABC method is applicable for hotel companies with a detailed cost accountng system.

As mentioned in the literature review section, the ABC method is not preferred in most of the accommodation companies due to the difficulty and complexity of installing the system and its cost. Instead, many accommodation companies prefer traditional costing methods. If accommodation companies prefer using ABC method to traditional costing methods, this study thought to be a guide in calculating costs more accurately thus reducing costs.

\section{ACTIVITY-BASED COSTING METHOD IN ACCOMMODATION COMPANIES}

Traditional costing methods have been widely used in manufacturing and service industries for hundreds of years. However, due to technological breakthroughs in industry in the 1980s, new costing methods were developed (Haroun, 2015: 259). One of these methods is Activity-Based Costing method, developed by Cooper and Kaplan in the early 1990s, this method is a methodology that measures the activities and resources of cost factors, cost, and performance. According to this method, cost factors consume activities while activities consume resources. In other words, it examines the causal relationships between cost factors and activities, and between activities and resources (Abbas and Wagdi, 2014).

\section{Definition and Purposes of Activity-Based Costing (ABC) Method}

ABC method is an important and widely used full costing method in accounting. This method states that in order to show the relationship between activities, resource consumption, and ultimately profit, it is necessary to start by focusing primarily on products. $\mathrm{ABC}$ is a method that measures cost objects such as products, customers, and services. $\mathrm{ABC}$ primarily attributes resource costs to activities performed by the company. In other words, activities consume resources, so products consume activities sequentially in the formation of costs.

$\mathrm{ABC}$ method has been developed to provide more accurate information than traditional costing methods in the calculation of product cost, especially when a large number of products are produced in companies or production processes become complex and the cost structure changes. $\mathrm{ABC}$ is a method for assigning the indirect costs to the products. Therefore, $\mathrm{ABC}$ method is an alternative to the traditional costing method that is based on production volume. One of the most 
perceived benefits of adopting $\mathrm{ABC}$ is more accurate cost information for product costing (Cooper and Kaplan, 1991: 131).

$\mathrm{ABC}$ method is applied in two stages. In the first stage, resource costs are collected in resource cost pools and these are then allocated to the activities. In the second stage, activity costs are collected in activity cost pools and then distributed to cost objects (Hoozee and Hansen, 2018: 144).

Although ABC method seems like an accounting model at first glance, it is a method designed to inform management about current, past, and future transactions in the company. Perceiving the purpose of this method as just distributing costs correctly may lead to ignoring essential functions such as managerial and strategic decision processes (Seldüz, 2013: 27).

In this context, the primary purposes of $\mathrm{ABC}$ method can be listed as follows (Eraslan, 2019: 10):

- To ensure the costs that add low values are minimized or eliminated by classifying the activities as creating or not creating added value.

- To create an effective and efficient information database to increase the functionality of the activities that contribute to meeting customer demands and thus positively affect profitability.

- Determining the causes of problems and determining the solutions.

- Correcting inaccurate cost allocations resulting from the inadequacies of traditional costing methods and some weak assumptions.

- Providing accurate cost information so that managers can make the right decisions.

\section{The Necessity of Using Activity-Based Costing Method In Accommodation Companies}

ABC method was developed in 1980s by Robin Cooper and Robert Kaplan in order to eliminate the shortcomings of traditional costing methods. The rapid increase in automation in production techniques, and the complexity of production systems in the early 1980s led to a rapid decrease in direct labor costs, which is one of the elements that constitute the production cost, and an increase in overhead costs, which is another cost element, at the same speed (Von BrandtSiemers, 201: 23).

When it comes to the accommodation industry, there is no distinction between direct raw materials, direct labor and overhead costs in hotel companies. Expenses can be followed as direct and indirect costs. The increased amount of indirect costs made it more sensitive to assign the costs to products and services. 
In addition, the fact that fixed costs are quite high compared to variable costs causes insufficient cost calculation. Traditional costing is insufficient, and fails to allocate these costs correctly. Because most of the costs are indirect. Therefore, using the $\mathrm{ABC}$ method in hotels will be beneficial in terms of obtaining more accurate costs (Ciğer, 2020: 167).

Some reasons for hotels to adopt $\mathrm{ABC}$ are as below (Patiar, 2016: 3):

- The implementation of effective product strategies through the correct distribution of indirect costs,

- Their positioning in a competitive market through the use of detailed cost information,

- More emphasis on activities that create added value,

- Achievement of organizational goals through cost control.

However, if hotels adopt more functional costing systems such as $\mathrm{ABC}$, accurate pricing that can reduce costs without providing low quality service will be able to make decisions, measure performance effectively, and make extensive use of cost data for other management applications (Pavlatos and Paggios, 2009: 523).

As a result, the $\mathrm{ABC}$ method is beneficial in the following cases (Patiar, 2016: 7):

- Indirect expenses (overhead costs) have a high share in total expenses since they are not directly allocatable to products.

- High product portfolio and product variety.

- It forces hotels to gain a cost advantage over their competitors. It increases efficiency in strategic and operational decisions. This increases profitability and financial performance.

\section{Disadvantages of Activity-Based Costing Method}

Although it is accepted as an important innovation in the field of cost accounting, difficulties in the application and maintenance of $\mathrm{ABC}$ system prevented $\mathrm{ABC}$ from being an efficient, current, and contemporary cost management tool. Some following criticisms are brought to the ABC method (Caner, 2019: 4; Salem and Mazhar, 2014: 41-42):

- The $\mathrm{ABC}$ method has a large number of cost pools and cost drivers. Therefore, it can be more complex than traditional costing methods.

- Some difficulties may arise in the application of the ABC method, such as the determination of cost drivers, the assignment of joint costs, and varying rates of cost drivers. 
- The application of $\mathrm{ABC}$ method requires a significant amount of time, and cost.

- Data on the ABC method can be subjective and difficult to verify.

- Collecting, storing, processing, and reporting data can be costly.

- The ABC method cannot be easily updated to suit changing conditions.

For these reasons, another costing system, Time-Driven Activity-Based Costing method, which is easier to implement and less costly than $\mathrm{ABC}$ and is a more updated version of $\mathrm{ABC}$ has been developed.

\section{LITERATURE REVIEW}

When the literature is reviewed, most of the studies on $\mathrm{ABC}$ have been carried out in production companies. In studies on $\mathrm{ABC}$ in accommodation companies, it has been concluded that $\mathrm{ABC}$ is superior to other traditional costing methods that are based on case studies. In addition, it is seen that some studies include survey applications to determine the adoption and application level of the method. Some studies on the subject are as follows:

Pavlatos and Ioannis (2009), conducted a survey of 85 hotel companies on the cost systems used by the Greek hotel industry. As a result of the study, they concluded that approximately $75 \%$ of the hotels in Greece apply traditional costing systems, and the rate of application of the activity-based costing method is higher than in other countries.

Zounta and Bekiaris (2009), examined the perceptions of hotel accountants and managers about cost-based management and decision making using the survey method. $71 \%$ of hotel companies are aware of $\mathrm{ABC}$, but it has been revealed that only $15 \%$ use the method.

El-Deeb et al. (2011), proposed to use a new model through the application of $\mathrm{ABC}$ approach that can be applied in the purchasing department to optimize the performance of purchasing activities. It has been determined that the ABC model increases the purchasing performance in the accommodation industry.

Vazakidis and Karagiannis (2011), aimed to discuss the outcome of implementing both traditional costing and Activity-Based Management models in a high level hotel enterprise. The data obtained from the analysis gave an idea about the organizational structure to the hotel management and help overtake current bottlenecks, and boundaries. The ABM method can be used effectively at budgeting and benchmarking. Also, this method gives an idea to the business about how the pricing policy should be. 
Köroğlu (2013), in his study, determined the stages of activity-based costing method in a hotel, then grouped the costs of the hotel in four main activity centers based on the cost data of the hotel, and uploaded the result to four different customer groups and found the unit cost.

Altuntaş (2014), in his study, aimed to measure the application level of ABC method in accommodation companies by survey method. As a result of the study, he emphasized that it is not easy to apply the $\mathrm{ABC}$ method in the accommodation sector, but with the application of the method, the costs can be determined more accurately, the use of capacity and efficiency can increase, and it is effective in reducing costs.

Alsoboa et al. (2015), examined the effects of using strategic decision making techniques on the performance of Jordanian hotels by using the survey method. It showed that $\mathrm{ABC}$ method and strategic decision making techniques have a statistically significant effect on the performance of Jordan hotels.

Mashayekhi and Ara (2017), aimed to provide some experimental evidence of $\mathrm{ABC}$ application in the accommodation sector in Iran and compare it with the traditional costing method. Different costs per unit were obtained in the two methods. ABC provides more accurate and detailed information.

Özer and Bilici (2017), aimed to investigate the applicability of ABC method at accommodation companies operating in the province of Van/Turkey. It has been revealed that companies implementing $\mathrm{ABC}$ calculate more accurate costs, but it is difficult to determine the activities while applying $\mathrm{ABC}$.

Faria et al. (2018), examined the degree of adoption of the activity-based costing method in performing customer profitability analysis in hotels using the survey method. It has been concluded that hotels do not adopt the ABC method and prefer to use traditional costing methods.

Karacan (2019), in his study, touched on the theoretical infrastructure of the activity-based costing method in tourism companies. He explained the $\mathrm{ABC}$ application with the case study method.

When the literature is reviewed in general, the case studies chosen as the method are usually the comparison of the traditional costing method with the ABC method. All of the studies given in the literature review section of the study have been applied in large-scale hotels. In the results of the studies, it has been observed that $\mathrm{ABC}$ gives more accurate cost and detailed information compared to the traditional costing method, creates flexibility in pricing, and has a positive effect on financial performance. It has been also revealed that $A B C$ produces more accurate information in customer profitability analysis and accordingly, 
managers use customer profitability analysis in pricing and strategic decisions. In the studies where the survey method was preferred, it was revealed that the ABC method was used in hotels little or no. However, their level of adoption was high. The obstacles to the application of $\mathrm{ABC}$ method were determined as the difficulty of determining the activities in accommodation companies and satisfaction with the current costing system.

As a result of the literature review, it has been determined that $A B C$ method is not widely used in hotel companies because it requires detailed data. Despite the rapid increase in the number of hotel businesses in Turkey, the lack of a large number of studies on costing and $\mathrm{ABC}$ method in hotels has been effective in conducting the study.

\section{THE CASE STUDY IN A 5-STAR HOTEL AND RESEARCH DESIGN}

The purpose of the study is to calculate the service cost produced in a 5-star hotel in Alanya/Antalya by applying ABC method and compare it with the cost calculated according to the traditional costing method. For the application of the $\mathrm{ABC}$ method, a decent 5-star international hotel was selected and accounting data in July 2019 was used for costing purposes through $\mathrm{ABC}$ and traditional methods. One of the co-authors of the study directly contacted the hotel manager and officials, and obtained first-hand data about the application. The exemplary accommodation company is currently using the traditional costing method to conduct its costing system. The data presented in the case study represent actual data gathered throughout the one month period of 2019.

The limitations of the study are as follows:

- Since some estimated data are used in the current cost system applied by the company, the information specified by the company managers is taken as basis.

-When applying the activity-based costing method, the main structure of the service cost, front office, housekeeping, service, kitchen and other services were examined.

- Since the purpose of the study is to calculate the service cost, the costs related to the management will be assigned by taking into account the number of overnight stays without entering the activities' details to complete the application.

- Due to the Covid-19 outbreak, the hotel could not serve for a long time in 2020. Therefore, 2019 data were used to make the calculations more accurate. 


\section{General Information About The Hotel}

The hotel is located on $12 \mathrm{~km}$ from Alanya and $45 \mathrm{~km}$ from Gazipaşa Airport and is open 12 months a year. Providing service with an all-inclusive concept, the hotel is established on an area of $23.000 \mathrm{~m}^{2}$ and is a family hotel with a large green area consisting of 6 blocks and a total of 350 rooms (with 700 beds capacity). The services included in the product are food, beverage, accommodation, Turkish bath-sauna, spa, bars, swimming pools, sports, and entertainment activities.

Busy periods of the hotel are between April-October and the peak period is June-July-August. With the effect of the characteristics of the Antalya region, the hotel works with the highest profit margin in the relevant periods and the customers come as a group through the travel agency. Hence, travel agencies play an important role in determining the sale price in an intense competitive environment.

The study is based on July 2019 data, and the average length of stay for customers is seven days. The company has an $80 \%$ occupancy rate in July. Also, $10 \%$ of the customers are children and $10 \%$ additional beds are used.

Room Occupancy Rate $=350$ x 0,80 $=280$ rooms

Beds Occupancy Rate $=700$ x 0,80 $=560$ person (adult)

The number of children $=280 \times 0,10=28$ children

The number of customers who can stay with additional bed $=280 \times 0,10=28$ person

Total number of customers per week $=616$ person

Total number of customers per month $=616 \times 4=2.464$ person

The number of overnight stays per month $=2.464 \times 7=17.248$

The number of personnel and square meters of areas in the hotel are listed below.

Table 1. Number of Personnel and Square Meters of Areas in the Hotel

\begin{tabular}{|c|c|c|c|}
\hline Department & $\begin{array}{l}\text { Number of } \\
\text { Personnel }\end{array}$ & Area & $\begin{array}{c}\text { Square Meters of } \\
\text { Areas }\left(\mathbf{m}^{2}\right)\end{array}$ \\
\hline Front Office & 14 & Front Office & 80 \\
\hline Housekeeping & 45 & Rooms & 7.800 \\
\hline Service & 35 & Park\&Garden & 7.500 \\
\hline
\end{tabular}




\begin{tabular}{|l|r|l|r|}
\hline Kitchen & 35 & Beach & 5.000 \\
\hline Animation & 10 & Service & 100 \\
\hline Park\&Garden & 11 & Kitchen & 400 \\
\hline Laundry & 9 & Restaurant & 660 \\
\hline Doctor & 1 & Laundry & 60 \\
\hline Security & 12 & Bars (Pool/Lobby) & 850 \\
\hline Administrative & 14 & Amfi Theatre & 300 \\
\hline Technical Service & 21 & Turkish Bath-Sauna & 250 \\
\hline Purchasing & 4 & & \\
\hline Accounting/Finance & 9 & & $\mathbf{2 3 . 0 0 0}$ \\
\hline TOTAL & $\mathbf{2 2 0}$ & TOTAL & \\
\hline
\end{tabular}

The July/2019 period expense information for the hotel is as follows:

Table 2. Expenses Incurred in July

\begin{tabular}{|l|r|}
\hline Expenses & $\begin{array}{r}\text { Amount } \\
(\mathbf{f})\end{array}$ \\
\hline Staff Food and Beverage & $48.901,32$ \\
\hline Transport Expenses & $33.780,61$ \\
\hline Electricity & $34.887,42$ \\
\hline Water & $9.215,89$ \\
\hline Landscape and Pool & $12.170,92$ \\
\hline Laundry & $3.685,93$ \\
\hline Phone & $11.245,36$ \\
\hline Depreciation & $295.481,55$ \\
\hline Food & $500.077,60$ \\
\hline Beverage & $318.647,67$ \\
\hline Cleaning Equipment & $27.687,13$ \\
\hline Stationery and Printed Forms & $7.214,20$ \\
\hline Chemical Materials & $14.863,10$ \\
\hline Boucle Materials & $4.756,82$ \\
\hline LPG & $52.450,50$ \\
\hline Vehicle Fuel & $18.960,00$ \\
\hline Service Materials & $2.417,36$ \\
\hline Maintenance & $9.250,85$ \\
\hline Spare Parts & $6.743,25$ \\
\hline Electrical Materials & $7.654,21$ \\
\hline Plumbing Materials & $2.637,35$ \\
\hline Personnel Wages & $1.216 .468,64$ \\
\hline TOTAL & $\mathbf{2 . 6 3 9 . 1 9 7 , 6 8}$ \\
\hline
\end{tabular}

Activity-Based Costing Method Application In the Hotel 
$\mathrm{ABC}$ implementation steps are as follows:

1- Determination of activities and activity cost centers

2- Determination of resource costs and activity cost drivers

3- Creating cost pools and allocation of resource costs to the activities

4- Determination of cost drivers

5- Allocation of activity costs to the service production cost

\section{Determination of Activities and Activity Cost Centers}

As a result of the investigations carried out in the hotel and face-to-face interviews with the hotel officials, it was determined that four main and one other (common and administrative expenses) activities were carried out in the hotel while determining these activity centers, care was taken to collect similar activities in a single activity pool. Thus, the creation of unnecessary activity centers was avoided. The following table lists the activity cost centers and subactivities at the case hotel.

Table 3. The Activity Cost Centers and Sub-Activities in the Hotel

\begin{tabular}{|l|l|}
\hline Activity Cost Centers & Sub-Activities \\
\hline \multirow{2}{*}{$\begin{array}{l}\text { Front Office Activity } \\
\text { Center }\end{array}$} & Welcoming Customers \\
\cline { 2 - 2 } & Making Reservations \\
\cline { 2 - 2 } & Check-in Processes \\
\hline & $\begin{array}{l}\text { Taking Customers to the rooms } \\
\text { Check-out Processes }\end{array}$ \\
\cline { 2 - 2 } & $\begin{array}{l}\text { Keeping and Controlling Customer Accounts } \\
\text { Making Night Reportings }\end{array}$ \\
\hline \multirow{3}{*}{$\begin{array}{l}\text { Housekeeping } \\
\text { Activity Center }\end{array}$} & $\begin{array}{l}\text { Cleaning and Arrangement of Occupied and Empty } \\
\text { Rooms } \\
\text { Control of the Rooms }\end{array}$ \\
\cline { 2 - 2 } & $\begin{array}{l}\text { Preparing reports on the situation of the rooms and } \\
\text { informing relevant units } \\
\text { Cleaning of Public Areas (including beach, pools, bars } \\
\text { and restaurant) }\end{array}$ \\
\hline $\begin{array}{l}\text { Services Activity } \\
\text { Center }\end{array}$ & $\begin{array}{l}\text { Preparation of Tables } \\
\text { Placing and drying service supplies after washing }\end{array}$ \\
\hline
\end{tabular}




\begin{tabular}{|l|l|}
\hline \multirow{5}{*}{$\begin{array}{l}\text { Kitchen Activity } \\
\text { Center }\end{array}$} & Removing the Service \\
\hline & Receiving and placing the orders \\
\hline \multirow{5}{*}{$\begin{array}{l}\text { Other Activity } \\
\text { Center }\end{array}$} & Cooking Food \\
\hline & Preparation of the buffet \\
\hline & Removing the buffet \\
\hline Scullery \\
\hline & Animation \\
\hline & Turkish bath-sauna-spa-fitness \\
\hline Beach and pool services \\
\hline & Park\&Garden \\
\hline Security \\
\hline & Laundry \\
\hline & Technical Service \\
\hline & Administrative \\
\hline & Other \\
\hline
\end{tabular}

\section{Determination of Resource Costs and Activity Cost Drivers}

Information obtained from the interviews with hotel managers, the resources and the activity cost drivers are given in Table 4.

Table 4. The Resources and Activity Cost Drivers

\begin{tabular}{|l|r|}
\hline Resources & Activity Cost Drivers \\
\hline Staff Food and Beverage & Number of Staff \\
\hline Transport Expenses & Number of Staff \\
\hline Electricity & $\mathrm{Kw} / \mathrm{h}$ \\
\hline Water & Ledger Entries \\
\hline Landscape and Pool & Ledger Entries \\
\hline Laundry & Ledger Entries \\
\hline Phone & Number of Staff \\
\hline Depreciation & Square Meters of Areas \\
\hline Food & Consumption Reports \\
\hline Beverage & Consumption Reports \\
\hline Cleaning Equipment & Consumption Reports \\
\hline
\end{tabular}


Ö.B.Paksoy-B.Yılmaz Implementation of Activity-Based Costing...

\begin{tabular}{|l|r|}
\hline Stationery and Printed Forms & Consumption Reports \\
\hline Chemical Materials & Consumption Reports \\
\hline Boucle Materials & Consumption Reports \\
\hline LPG & Ledger Entries \\
\hline Vehicle Fuel & Oil Receipts \\
\hline Service Materials & Consumption Reports \\
\hline Maintenance & Ledger Entries \\
\hline Spare Parts & Consumption Reports \\
\hline Electrical Materials & Consumption Reports \\
\hline Plumbing Materials & Consumption Reports \\
\hline Personnel Wages & Department Payrolls \\
\hline
\end{tabular}

\section{Creating Cost Pools and Allocation of Resource Costs to the Activities}

At this stage, the cost driver for each expense is determined and distributed to the activity centers. The distribution of the costs of the hotel applied in the study is given in Table 5 .

Table 5. Allocation of the Costs to the Activity Cost Centers

\begin{tabular}{|l|l|l|l|l|l|l|l|}
\hline \multicolumn{1}{|c|}{$\begin{array}{c}\text { Resource } \\
\text { Costs }\end{array}$} & \multicolumn{1}{|c|}{$\begin{array}{c}\text { Activity } \\
\text { Cost } \\
\text { Drivers }\end{array}$} & \multicolumn{5}{|c|}{ ACTIVITY COST CENTERS } & \multicolumn{1}{|l|}{$\begin{array}{c}\text { TOTAL } \\
(\mathbf{(})\end{array}$} \\
\hline & & $\begin{array}{l}\text { Front } \\
\text { Office }\end{array}$ & Housekeeping & Service & Kitchen & Other & \\
\hline $\begin{array}{l}\text { Staff Food } \\
\text { and } \\
\text { Beverage }\end{array}$ & $\begin{array}{l}\text { Number of } \\
\text { Staff }\end{array}$ & $3.111,90$ & $10.002,54$ & $7.779,76$ & $7.779,76$ & $20.227,36$ & $48.901,32$ \\
\hline $\begin{array}{l}\text { Transport } \\
\text { Expenses }\end{array}$ & $\begin{array}{l}\text { Number of } \\
\text { Staff }\end{array}$ & $2.149,68$ & $6.909,67$ & $5.374,19$ & $5.374,19$ & $13.972,89$ & $33.780,61$ \\
\hline Electricity & Kw/h & $1.744,37$ & $16.745,96$ & $3.139,87$ & $6.977,48$ & $6.279,74$ & $34.887,42$ \\
\hline Water & $\begin{array}{l}\text { Ledger } \\
\text { Entries }\end{array}$ & & $4.147,15$ & $1.013,75$ & $2.764,77$ & $1.290,22$ & $9.215,89$ \\
\hline
\end{tabular}

\footnotetext{
${ }^{2}$ Due to the page and word constraints, not all distributions are shown, staff food and beverage expenses are given as an example. Total staff food and beverage consumption is 48.901,32 TL and the total number of staff is 220 . The overhead allocation rate is calculated as $222,278 \mathrm{TL} / \mathrm{staff}$. The distribution of food and beverage expenses of the personnel within the number of personnel working in the hotel departments to the activity centers is as follows;

Front Office $=14 \times 222,278=3.111,90 \mathrm{TL}$

Housekeeping $=45 \times 222,278=10.002,54 \mathrm{TL}$

Service $=35 \times 222,278=7.779,76 \mathrm{TL}$

Kitchen $=35 \times 222,278=7.779,76 \mathrm{TL}$

Other $=91 \times 222,278=20.227,36 \mathrm{TL}$
} 
KSÜSBD

Vol: 18 Issue: 3 / December 2021

\begin{tabular}{|c|c|c|c|c|c|c|c|}
\hline $\begin{array}{l}\text { Landscape } \\
\text { and Pool }\end{array}$ & $\begin{array}{l}\text { Ledger } \\
\text { Entries }\end{array}$ & & & & & $12.170,92$ & $12.170,92$ \\
\hline Laundry & $\begin{array}{l}\text { Ledger } \\
\text { Entries }\end{array}$ & & $3.685,93$ & & & & $3.685,93$ \\
\hline Phone & $\begin{array}{l}\text { Number of } \\
\text { Staff }\end{array}$ & 715,61 & $2.300,19$ & $1.789,03$ & $1.789,03$ & $4.651,49$ & $11.245,36$ \\
\hline Depreciation & $\begin{array}{l}\text { Square } \\
\text { Meters of } \\
\text { Areas }\end{array}$ & $1.027,76$ & $100.977,61$ & $20.683,71$ & $5.138,81$ & $167.653,66$ & $295.481,55$ \\
\hline Food & $\begin{array}{l}\text { Consumption } \\
\text { Reports }\end{array}$ & & & & $500.077,60$ & & $500.077,60$ \\
\hline Beverage & $\begin{array}{l}\text { Consumption } \\
\text { Reports }\end{array}$ & & & $318.647,67$ & & & $318.647,67$ \\
\hline $\begin{array}{l}\text { Cleaning } \\
\text { Equipment }\end{array}$ & $\begin{array}{l}\text { Consumption } \\
\text { Reports }\end{array}$ & & $8.029,27$ & & & $19.657,86$ & $27.687,13$ \\
\hline $\begin{array}{l}\text { Stationery } \\
\text { and Printed } \\
\text { Forms }\end{array}$ & $\begin{array}{l}\text { Consumption } \\
\text { Reports }\end{array}$ & $2.524,97$ & 786,45 & 654,87 & 542,92 & $2.704,99$ & $7.214,20$ \\
\hline $\begin{array}{l}\text { Chemical } \\
\text { Materials } \\
\end{array}$ & $\begin{array}{l}\text { Consumption } \\
\text { Reports }\end{array}$ & & & & & $14.863,10$ & $14.863,10$ \\
\hline $\begin{array}{l}\text { Boucle } \\
\text { Materials }\end{array}$ & $\begin{array}{l}\text { Consumption } \\
\text { Reports }\end{array}$ & & $4.756,82$ & & & & $4.756,82$ \\
\hline LPG & $\begin{array}{l}\text { Ledger } \\
\text { Entries }\end{array}$ & & & & $12.150,25$ & $40.300,25$ & $52.450,50$ \\
\hline Vehicle Fuel & Oil Receipts & & & & & $18.960,00$ & $18.960,00$ \\
\hline $\begin{array}{l}\text { Service } \\
\text { Materials } \\
\end{array}$ & $\begin{array}{l}\text { Consumption } \\
\text { Reports }\end{array}$ & & & $2.417,36$ & & & $2.417,36$ \\
\hline Maintenance & $\begin{array}{l}\text { Ledger } \\
\text { Entries }\end{array}$ & $1.110,10$ & $2.590,24$ & & $4.440,41$ & $1.110,10$ & $9.250,85$ \\
\hline Spare Parts & $\begin{array}{l}\text { Consumption } \\
\text { Reports }\end{array}$ & 809,19 & $5.259,74$ & & & 674,33 & $6.743,25$ \\
\hline $\begin{array}{l}\text { Electrical } \\
\text { Materials } \\
\end{array}$ & $\begin{array}{l}\text { Consumption } \\
\text { Reports } \\
\end{array}$ & 382,71 & $6.123,37$ & & & $1.148,13$ & $7.654,21$ \\
\hline $\begin{array}{l}\text { Plumbing } \\
\text { Materials }\end{array}$ & $\begin{array}{l}\text { Consumption } \\
\text { Reports }\end{array}$ & & 369,23 & & 316,48 & $1.951,64$ & $2.637,35$ \\
\hline $\begin{array}{l}\text { Personnel } \\
\text { Wages }\end{array}$ & $\begin{array}{l}\text { Department } \\
\text { Payrolls }\end{array}$ & $77.411,64$ & $248.823,13$ & $193.529,10$ & $208.329,10$ & $488.375,66$ & $1.216 .468,64$ \\
\hline \multicolumn{2}{|c|}{$\begin{array}{l}\text { TOTAL (ACTIVITY COST } \\
\text { CENTERS) }\end{array}$} & $90.987,94$ & 421.507,29 & $555.029,30$ & $755.680,80$ & $815.992,34$ & $2.639 .197,68$ \\
\hline
\end{tabular}

The distribution of total costs by activity centers is as follows; $3.45 \%$ is front office, $15.97 \%$ housekeeping, $21.03 \%$ service, $28.63 \%$ kitchen, and $30.92 \%$ other departments. Approximately $30 \%$ of the expenses in the other activity center consist of common expenses that concern the entire company and expenses related to administrative units such as management, security, purchasing, accounting, marketing, and human resources. There is no direct relationship with the consumption of the activities. 
$\underline{\text { Ö.B.Paksoy-B.Yılmaz } \quad \text { Implementation of Activity-Based Costing... }}$

The total service cost of the hotel is 2.187.630,10 TL. But the total cost of the company is 2.639.197,68 TL. Management, security, purchasing, accounting, marketing, and human resources related expenses are also included in the total cost. Expenses related to this type of activities are not included in the service production cost. Out of service non-allocated expenses are listed in the table 6 below.

Table 6. Non-Allocated Expenses

\begin{tabular}{|l|r|}
\hline Departments & $\begin{array}{r}\text { Expenses } \\
(\mathbf{f})\end{array}$ \\
\hline Sales and Marketing & $67.735,14$ \\
\hline Administration & $56.445,95$ \\
\hline Accounting \& Finance & $101.602,71$ \\
\hline Doctor & $11.289,19$ \\
\hline Security & $135.470,27$ \\
\hline Purchasing & $45.156,76$ \\
\hline Human Resources & $33.867,57$ \\
\hline TOTAL & $\mathbf{4 5 1 . 5 6 7 , 5 8}$ \\
\hline
\end{tabular}

As shown in the table above, 451.567,58 TL of 815.992,34 TL has been allocated to the operating expenses not included in the service cost. The remaining amount $(364.424,76 \mathrm{TL})$ is distributed to the activity centers within the number of personnel and is shown in the table below.

Table 7. Distribution of Other Activity Cost Center Expenses

\begin{tabular}{|l|c|r|r|r|}
\hline Activity Cost Centers & $\begin{array}{c}\text { Cost of } \\
\text { Other } \\
\text { Activity } \\
\text { Center }\end{array}$ & $\begin{array}{c}\text { Overhead } \\
\text { Allocation } \\
\text { Rate }\end{array}$ & $\begin{array}{c}\text { Allocation } \\
\text { Amount } \\
(\mathbf{f})\end{array}$ & $\begin{array}{c}\text { Activity } \\
\text { Center Total } \\
\text { Costs } \\
(\mathbf{f})\end{array}$ \\
\hline Front Office & $364.424,76$ & 0,11 & $39.549,97$ & $130.537,91$ \\
\hline Housekeeping & $364.424,76$ & 0,35 & $127.124,92$ & $548.632,21$ \\
\hline Service & $364.424,76$ & 0,27 & $98.874,94$ & $653.904,24$ \\
\hline Kitchen & $364.424,76$ & 0,27 & $98.874,94$ & $854.555,74$ \\
\hline TOTAL & & $\mathbf{1 , 0 0}$ & $\mathbf{3 6 4 . 4 2 4 , 7 6}$ & $\mathbf{2 . 1 8 7 . 6 3 0 , 1 0}$ \\
\hline
\end{tabular}




\section{Determination of Cost Drivers}

Distribution keys must first be assigned to the activities in order to add the general production expenses accumulated in the activities to the service cost. The activity distribution keys determined within this scope are shown below:

Table 8. Determination of Cost Drivers

\begin{tabular}{|l|l|}
\hline Activities & Cost Drivers \\
\hline Front Office & Number of Customers \\
\hline Housekeeping & Number of Activities \\
\hline Service & Number of Overnight Stays \\
\hline Kitchen & Number of Overnight Stays \\
\hline
\end{tabular}

As shown in the table above, to allocate the costs accumulated in the activities to the service, the appropriate activity cost drivers that will best represent the relevant activity have been determined.

\section{a) Front Office}

It is the unit that accepts customers who come to stay in the hotel, performs reservation, registration, room, baggage, account, fee collection, message and communication transactions, and informs guests about activities inside and outside the hotel.

Expenses in this activity center can generally be given as electricity, water, depreciation, personnel wages, stationery and other expense groups as seen above. While determining the cost driver for this activity center, the most appropriate driver was determined. As a result, this activity center is directly customer-oriented and serves accordingly, so the total number of customers staying at the hotel is taken into account. The total number of customers in July was 2.464 .

Room Occupancy Rate $=350 \times 0,80=280$ rooms

Beds Occupancy Rate $=700$ x $0,80=560$ person (adult)

The number of children $=280 \times 0,10=28$ children

The number of customers who can stay with additional bed $=280 \times 0,10=28$ person 
Total number of customers per week $=616$ person

Total number of customers per month $=616 \times 4=2.464$ person

\section{b) Housekeeping}

The housekeeping department performs all works related to the cleaning, order and maintenance of the hotel. In an accommodation company, housekeeping department cleans, preserves, and maintains guest rooms, corridors and general areas. In addition, it carries out the cleaning, preservation and decoration of the hotel and guest linen. The guest wants comfort and attention at home in a safe and quiet environment. He wants the service he receives to be perfect in return for his expenses. For this reason, housekeeping staff should know the expectations of the guests well. The housekeeping staff who create positive and negative impressions of the guest about the company are a whole. The housekeeping workers should know the place and importance of this department in the accommodation company, and employees should be arranged accordingly.

The most appropriate cost driver for this department will be the hotel's total number of housekeeping activities. The hotel has a total of 350 rooms. Since the month of application is July, which is a high season, a total of 45 people work in housekeeping services that month. Their daily activities are 350 x $45=15.750$ times a day and these activities are calculated as $15.750 \times 30=472.500$ times/month for that month.

\section{c) Service}

Food and beverage service; it is the profession and art of presenting the food and beverages desired by the guests within certain rules, satisfying them by acting according to their social and psychological conditions and providing the highest possible income to the company.

Service department, in general, is in cooperation with all departments of a hotel. For the preparation of the restaurant and kitchen, forecast from the front office is as important as it is necessary at the check outs. In addition to this daily information, forward-looking reservation information to see the future, the data of special guests such as room number, number of people and the type of food are available in the front office. For this reason, the most appropriate cost driver will be the total number of overnight stays of customers in July.

Total number of customers per week $=616$ person

Total number of customers per month $=616 \times 4=2.464$ person 
The number of overnight stays per month $=2.464 \times 7=17.248$

\section{d) Kitchen}

When evaluating the quality of the service offered by the hotel companies, not only the rooms and the furniture in these rooms are taken into account, but also the quality of the food and drinks offered by the hotel. Food produced in the kitchen is of great importance in terms of quality. Quality food production has a positive effect on customer satisfaction. It is very important that the dishes desired by the customers are included in the menus, that these foods are delicious, nutritious and pleasant, and that hygiene rules are followed during the production and service of the meals. For the kitchen department, the total number of overnight stays will be the most appropriate cost driver, as in the service department.

\section{Allocation of Activity Costs to the Service Production Cost}

Assigning the activity costs to the service cost through cost drivers is as follows:

Table 9. Calculation of Service Cost

\begin{tabular}{|l|l|r|r|}
\hline $\begin{array}{l}\text { Activity } \\
\text { Centers }\end{array}$ & Cost Drivers & $\begin{array}{r}\text { Total Cost of } \\
\text { Activities } \\
(\mathbf{f})\end{array}$ & $\begin{array}{r}\text { Unit Cost of Service } \\
(\mathbf{f})\end{array}$ \\
\hline Front Office & Number of Customers = 2.464 person & $130.537,91$ & $(130.537,91 / 2.464)=52,98$ \\
\hline Housekeeping & Number of Activities $=472.500$ times & $548.632,21$ & $(548.632,21 / 472.500)=1,16$ \\
\hline Service & Number of Overnight Stays = 17.248 O/N stays & $653.904,24$ & $(653.904,24 / 17.248)=37,91$ \\
\hline Kitchen & Number of Overnight Stays = 17.248 O/N stays & $854.555,74$ & $(854.555,74 / 17.248)=49,55$ \\
\hline TOTAL & & $\mathbf{2 . 1 8 7 . 6 3 0 , 1 0}$ & $\mathbf{1 4 1 , 6 0}$ \\
\hline
\end{tabular}

Within the unit cost determined above, the costs of administrative units such as marketing, human resources, security, doctor, purchasing, accounting, and finance, which were previously subtracted from the total cost, are not included. Normally, this stated administrative expenses are included in the total cost. These expenses will be assigned on the cost object based on the number of overnight stays.

The total administrative expenses is $451.567,58 \mathrm{TL}$ and the unit cost will be 26,18 TL (451.567,58/17.248). Total unit cost according to ABC method has been calculated as 167,78 TL (141,60 TL+26,18 TL). According to the traditional 
costing method, if the number of overnight stays is taken as the cost driver, the total unit cost is calculated as 153,02 TL (2.639.197,68 / 17.248).

The unit cost according to the $\mathrm{ABC}$ method turned out to be almost the same as the unit cost calculated according to the traditional costing method. Because in the $\mathrm{ABC}$ method, the cost of each activity was calculated separately, and different cost drivers were used.

\section{CONCLUSION}

Accurate calculation of cost data is vital for companies in almost every sector in the intense competitive environment in order to hold on to the market and survive. Misinformation about the costs of companies can greatly hinder their capacity to do and maintain business. Accurate cost information enables managers to measure profit to make the best decisions for the future of the company. Whether the business is a production, trade or service business may cause some differences in the calculation of cost data.

In Turkey, the number of companies operating in the tourism sector, especially hotels, is increasing every year. This increase in the number of hotels has made it very difficult for hotels to maintain and improve their profit margins. As a result, the costs incurred by hotels have increased and their profit margins have declined. Therefore, hotels should strategically manage their costs in order to survive in the highly competitive tourism industry.

In the study, the total unit service cost is calculated as 153,02 TL according to the traditional costing method. In the activity-based costing method, unit cost is calculated as $52,98 \mathrm{TL}$ in the front office activity center, $1,16 \mathrm{TL}$ in the housekeeping activity center, 37,91 TL in the service activity center, and 49,55 $\mathrm{TL}$ in the kitchen activity center. By adding up these unit costs incurred in the activity centers, the total unit service cost was calculated as 141,60 TL.

According to the traditional costing method, the cost of each customer receiving service from the hotel is $153,02 €$, and the management will continue its activities by making a pricing and service decision based on this cost. The service fee of a more costly department may be cheaper, and the service fee of a less costly department may be higher. This may cause customers to question the hotel's pricing policies.

The purpose of comparing the $\mathrm{ABC}$ method with the traditional costing method is not to show the costs of the ABC method lower or higher, but to allow the cost of each department and customer to be calculated in the most accurate way. While the $\mathrm{ABC}$ method realizes this purpose, it aims to reach the most rational result by distributing the indirect costs with its unique method. 
The reason for the lower service unit cost according to the $\mathrm{ABC}$ method in the study is that the administrative costs are not taken into account. When these costs are taken into account, it reaches the same level as the unit cost calculated according to the traditional costing method. If, in the study, the number of customers were chosen as the cost driver instead of the number of overnight stays in the distribution of costs in some activity centers, the unit cost would be approximately 7-8 times higher. That's why the determination of accurate activity drivers is very important.

The fact that the number of transactions in front office activities is not directly proportional to the number of overnight stays differs from the traditional cost in calculating the cost of these activities. For example, although the registration of the customers to the room is done once for each customer, the total cost realized in the front office without considering the activities in traditional costing is assigned on a single cost driver and the unit cost is calculated. Therefore, it cannot be calculated how much the activities carried out in the front office have on the service cost. The hotel calculates the cost of the activities by applying the ABC method, to accurately determine which activity has a positive or negative impact on the company, and the performance of its activities and employees.

On the other hand, in order to increase the performance of the service activities, the company can train its employees by examining the costs of the activities, recruit new employees or fire personnel if they have a negative contribution to the realization of the activity.

There are also studies in the literature that show similarities with the data obtained as a result of the application. Köroğlu (2013), in his study, calculated the cost of customer groups in a hotel and emphasized that the ABC method is more effective when calculating costs. Altuntaş (2014), in his study, emphasized that it is not easy to apply the ABC method in the accommodation sector, but with the application of the method, the costs are determined more accurately, the use of capacity and efficiency can increase and it is effective in reducing costs.

As a result of the study, it is concluded that $\mathrm{ABC}$ is applicable in the accommodation sector similar to the literature related to the $\mathrm{ABC}$ methods in this field. However, in this study, unlike other studies in the literature, the cost calculated with the $\mathrm{ABC}$ method was higher than the traditional costing method. Determining the accurate cost drivers based on actual data for a hotel can play a key role in cost management. In addition, determining the cost information on the basis of activity makes it easier for the hotel to make decisions on the basis of activities. 
However, it has been concluded that the application of $\mathrm{ABC}$ in accommodation companies is effective in reducing costs and capacity utilization of companies, more accurate cost data can be obtained with $\mathrm{ABC}$ and it would be beneficial to analyze the activities separately. Moreover, this method provides more detailed, healthy and precise information, leading managers to make more accurate and strategic decisions such as customer profitability, pricing and budgeting. Therefore, ABC method is highly recommended especially for the accommodation companies. However, it should be considered that the method is costly and time-consuming.

\section{REFERENCES}

Abbas, K. and Wagdi, O. (2014, May 16-17). Cost systems adoption in Egyptian manufacturing firms: competitive study between $A B C$ and RCA systems. 21st International Economic Conference - IECS, Sibiu, Romania. Available at SSRN: https://ssrn.com/abstract=2447454.

Alsoboa, S., Nawaiseh, M.E., Karaki, B.A. and Al Khattab, S. (2015). The impact of usage of strategic decision making techniques on Jordanian hotels' performance, International Journal of Applied Science and Technology, 5(1), 154-165.

Altuntaş, C. (2014). Konaklama işletmelerinde faaliyet tabanlı maliyet sisteminin uygulanabilirliğine yönelik bir araştırma, Mehmet Akif Ersoy Üniversitesi Iktisadi ve İdari Bilimler Fakültesi Dergisi, 1(1), 54-69.

Caner, G. (2019). Zaman sürücülü faaliyet tabanlı maliyetleme sistemi bir mermer işletmesi uygulaması, Muhasebe ve Finansman Dergisi, 2019(82), $1-20$.

Ciğer, A. (2020). Konaklama işletmelerinde faaliyet tabanlı maliyetleme yöntemi: bir otel işletmesinde vaka çalışması, Selçuk Üniversitesi Sosyal Bilimler Meslek Yüksekokulu Dergisi, 23(1), 164-185.

Cooper, R. and Kaplan, R.S. (1991). Profit priorities from activity-based costing, Harvard Business Review, 69(3), 130-135.

El-Deeb, M.S., Tawfik, Y., Bassim, M.A. and Elwy, E. (2011). Activity based costing (ABC) as an approach to optimize purchasing performance in hospitality industry, Internatıonal Journal Of Social Sciences and Humanity Studies, 3(2), 319-329. 
Eraslan, S. (2019). Faaliyet tabanlı maliyetleme ve zamana dayall faaliyet tabanlı maliyetleme sisteminin bir sanayi işletmesinde uygulanmast, [Doctoral dissertation, Osmaniye Korkut Ata University].

Faria, A.R., Ferreira, L. and Trigueiros, D. (2018). Analyzing customer profitability in hotels using activity based costing, Tourism \& Management Studies, 14(3), 65-74.

Gosselin, M. (2007). A review of activity-based costing: technique, implementation, and consequences, Handbooks of Management Accounting Research, 2, 641-671.

Haroun, A.E. (2015). Maintenance cost estimation: application of activity based costing as a fair estimate method, Journal of Quality in Maintenance Engineering, 21(3), 258-270.

Holjevac, I.A. (2003). A vision of tourism and the hotel industry in the $21 \mathrm{st}$ century, International Journal of Hospitality Management, 22(2), 129134.

Hoozée, S. and Hansen, S.C. (2018). A comparison of activity-based costing and time-driven activity based costing, Journal of Management Accounting Research, 30(1), 143-167.

Karacan, S. (2019, 30 May). Turizm işletmelerinde faaliyet tabanl maliyetleme yönteminin kullanilmast. Procedings of 3th ICTEBS, Available at: https://www.academia.edu/download/61473731/ICTEBS_2019_LASTD RAFT25.11.201920191210-26643-yj00z4.pdf.

Kaygusuzoğlu, M. (2010). Üretim maliyetlerindeki yapısal değişmelerin nedenleri ve maliyetleme kararlarına etkileri, Elektronik Sosyal Bilimler Dergisi, 9(34), 240-258.

Köroğlu, Ç. (2013). Otel işletmelerinde rekabet üstünlüğü elde etmek için bir ileri yönetim muhasebesi yöntemi olarak faaliyet tabanlı maliyetleme yönteminin analizi, Muhasebe ve Finansman Dergisi, 57, 39- 56.

Kurtlu, A. and Selçuk, Ş. (2020). Bir konaklama işletmesinin alakart restoranında kaynak tüketim muhasebesi uygulaması, Alanya Akademik Bakış Dergisi, 4(2), 261-281.

Mashayekhi, B. and Ara, M. (2017). Activity-based costing in the hospitality industry: a case study in a hotel, World Academy of Science, Engineering 
and Technology International Journal of Social and Tourism Sciences, 11(9), 2180-2184.

Özer, S. and Bilici, N. (2017). Konaklama işletmelerinde faaliyet tabanlı maliyetleme yönteminin uygulanabilirliğinin araştırılması: Van il merkezindeki otel işletmelerinde bir uygulama, Artvin Çoruh Üniversitesi Uluslararası Sosyal Bilimler Dergisi, 3(2), 1-22.

Patiar, A. (2016). Costs allocation practices: evidence of hotels in Australia, Journal of Hospitality and Tourism Management, 26, 1-8.

Pavlatos, O. and Paggios, I. (2009). Activity-based costing in the hospitality industry: evidence from Greece, Journal Of Hospitality \& Tourism Research, 33(4), 511-527.

Salem, S.E.A. and Mazhar, S. (2014). The benefits of the application of activitybased cost system-field study on manufacturing companies operating in Allahabad City-India, IOSR Journal of Business and Management, 16(11), 39-45.

Seldüz, H. (2013). Sağlık işletmelerinde faaliyet haritaları temelinde faaliyete dayalı maliyet yönetimi (1. Baskl). Ekin Basım Yayıncılık, Bursa.

TURSAB (2020, 20 February). https://www.tursab.org.tr/.

UNWTO (2020, 20 February). International tourism highlights 2020 edition. https://www.e-unwto.org/doi/epdf/10.18111/9789284422456.

Vazakidis, A. and Karagiannis, I. (2011). Activity-based management and traditional costing in tourist enterprises (a hotel implementation model), Operational Research IntJ, 11, 123-147.

Von Brandt-Siemers, J.B. (2019). Activity-based costing in higher education, [Doctoral dissertation, Capella University School of Business and Technology].

Zounta, S. and Bekiaris, M.G. (2009, 20 February). Cost-based management and decision making in Greek luxury hotels. Available at: https://mpra.ub.unimuenchen.de/25459/1/MPRA_paper_25459.pdf. 